\title{
EFEKTIVITAS SISTEM JARINGAN DOKUMENTASI DAN INFORMASI HUKUM (SJDIH) DI DAERAH ISTIMEWA YOGYAKARTA
}

\author{
Oleh Sri Rumani*), Agus Dwiyanto**), Ag. Subarsono**)
}

\begin{abstract}
This paper describes the implementation of Law Information and Documentation System on Government of Yogyakarta Special Territory base on the Man Power Capability (X1) technology (X2), organization climate (X3), commitments of group member $(X 4)$ and leadership style (X5). The results show that man power capability $(X 1)$ does not influence significantly to effectiveness, while technology $(X 2)$, organization climate $(X 3)$, commitments of group member $(X 4)$ and leadership style (X5) have influence on effectiveness significantly although in the range of low to middle value.

Leadership style (X5) of the leader in the Documentation and Information Network System (DINS) unit through analysis by using product moment and multiple linier regression prove that it has a great influence on effectiveness so whether the Documentation and Information Network System (DINS) on Government of Yogyakarta Special Territory is effective or not depends on leadership style of the leader.
\end{abstract}

Keywords: Effectiveness, Law-DINS, DIY

*). Librarian of Law Library of Gadjah Mada University

**). Teaching Staff, Faculty of Social and Political Sciences, Gadjah Mada University

\section{ABSTRAK}

Tulisan ini memaparkan hasil penelitian tentang efektivitas Sistem Jaringan Dokumentasi dan Informasi Hukum (SJDI) di Daerah Istimewa Yogyakarta (DIY) dilihat dari factor kemampuan sumber daya manusia, teknologi, iklim organisasi, komitmen anggota jaringan dan gaya kepemimpinan.

Hasil penelitian menunjukkan bahwa kemampuan SDM tidak begitu berpengaruh terhadap efektivitas jaringan dibandingkan dengan factor yang lain. Disamping itu ditunjukkan bahwa gaya kepemimpinan mempunyai pengaruh terbesar pada efektivitas Sistem Jaringan Dokumentasi dan Informasi (SJDI)

Kata Kunci: Efektivitas, Hukum-SJDI, DIY

*). Pustakawan Fakultas Hukum Universitas Gadjah Mada, Yogyakarta

**). Staf Pengajar Fakultas Ilmu Sosial dan Ilmu Politik, UniversitasGadjah Mada, Yogyakarta

\section{PENDAHULUAN}

Dalam masyarakat global di abad 21, informasi merupakan kebutuhan, komoditas, dan kekuatan. Dikatakan demikian karena informasi menjadi sesuatu yang dibutuhkan banyak orang, menjadi investasi yang layak dibisniskan. Oleh karena itu bagi mereka yang memiliki informasi, merekalah yang memiliki kekuatan dan kekuasaan.

Produk hukum dari badan-badan pemerintah tingkat pusat dan daerah merupakan salah satu informasi yang sangat diperlukan semua orang (birokrat, praktisi, akademisi, peneliti, pelaku bisnis dan masyarakat umum). Produk itu berbentuk UUD, TAP MPR, UU, Peraturan Pemerintah Pengganti Undang-undang/Perpu, Peraturan Pemerintah, Keputusan Presiden, Keputusan Menteri, sampai Peraturan Daerah. Semua jenis peraturan perundang-undangan ini menjadi bahan baku informasi hukum yang perannya penting dan strategis di negara hukum seperti di Indonesia.

Penjelasan UUD 1945 mengatakan bahwa sistem pemerintahan negara Indonesia berdasarkan atas hukum/ rechtsstaat, tidak berdasarkan atas kekuasaan belaka/ 
machtsstaat. Hal ini berarti bahwa hukum mempunyai peran sentral dan strategis sebagai pengarah dan pengayom dalam menjalankan kehidupan bernegara, berbangsa, dan bermasyarakat. Hukum positif menjadi dasar dalam ségala kehidupan, sehingga tidak semata-mata berdasarkan kekuasaan belaka. Hukum positif /iuscontitutum adalah hukum yang sedang berlaku, identik dengan peraturan perundang-undangan.

Peraturan perundangan yang menjadi nafas dari negara hukum, mempunyai konsekuensi bahwa semua aspek kehidupan diatur dalam peraturan perundangan. Sebab hakekat dari hukum itu sendiri adalah mengatur, mengusahakan ketertiban, dan membatasi subjek hukum. Tegaknya peraturan oleh aparat penegak hukum menjadi indikasi adanya supremasi hukum. Keadaan ini dapat terwujud apabila informasi hukum tersedia dan mudah diakses dengan cepat, tepat, akurat, mudah, dan murah. Informasi hukum juga penting, mengingat adanya fiksi/persangkaan hukum, yaitu setiap orang dianggap telah mengetahui adanya peraturan/ undang-undang liedereen wordt geacht de wet te kennen, nemo ius ignorare consetur yang artinya ketidaktahuan terhadap undang-undang tidak merupakan alasan pemaaf/ ignorantia legis excusat neminem. Kenyataannya tidak semua orang mengetahui peraturan perundangan yang sudah dan sedang diberlakukan, obyek yang diatur, kapan berlakunya, sudah dicabut/diganti nomor dan tahun penggantinya. Hal ini dapat terjadi karena informasi hukum ternyata sulit ditelusur, diakses, dan mahal.

Dampak dari kondisi ini adalah sering terjadi pembatalan transaksi dan profit margin yang lebih tinggi dari pada apa yang sebenarnya untuk mengimbangi resiko yang disebabkan oleh ketidak pastian hukum. Bisa juga terjadi tumpang tindih dan pertentangan antara peraturan yang satu dengan peraturan lainnya $\mathrm{Hal}$ ini bisa terjadi karena informasi hukum yang menjadi acuan kurang lengkap atau tidak diketemukan. Fungsi informasi hukum dalam penataan lembaga hukum antara lain; untuk penegakan, pelayanan, bantuan hukum, sebagai pedoman dan dasar penyidikan, serta utuk penuntutan dan pengambilan keputusan.

Apabila informasi hukum sulit ditelusur dan diakses dibiarkan terus, dampaknya dapat mengganggu proses ketaatan pada hukum, penegakan supremasi hukum dan budaya hukum di Indonesia.

Bukti bila informasi hukum sulit diakses dan ditelusur adalah penelitian yang pernah dilakukan pada tahun 1980 di Eropa. Ternyata lebih kurang 30 persen dari waktu kerja para ahli hukum digunakan untuk mencari informasi hukum tertulis yang relevan, dan ini merupakan jenis pekerjaan yang intensif dan berarti mahal (Jan Smits, 1991:111). Kemudian penelitian yang dilakukan oleh Bappenas dan Bank Dunia pada tahun 1996, dikatakan bahwa kemampuan lembaga-lembaga hukum pemerintah dalam hal dokumentasi dan informasi hukum masih lemah dalam memberikan akses informasi kepada masyarakat (Law Reporm, 1997:90-91 dalam Mardjono Reksodiputro, 2000:4). Sedang menurut Gregory Churchill (1989:5) dalam melakukan penelusuran literatur hukum di Indonesia akan langsung berhadapan dengan kenyataan bahwa sarana yang tersedia belum sepenuhnya mendukung usaha penelusuran. Sarana seperti perpustakaan dan pusat dokumentasi masih dalam pengembangan dan masih menghadapi banyak masalah dan tantangan.

Suatu realita bahwa perpustakaan dan pusat dokumentasi hukum yang masih menghadapi masalah dan tantangan menjadi kendala tersendiri bagi penyebarluasan dan pelayanan informasi hukum. Untuk itu ditempuh upaya agar dapat memperlancar akses dan penelusuran informasi hukum maka dibentuk Sistem Jaringan Dokumentasi dan Informasi (SJDI) Hukum di Indonesia sejak tahun 1974. Walaupun dalam GBHN 1993 dan 1999 telah ditekankan perlu ada perpustakaan hukum yang lengkap dan SJDI Hukum yang 
efektif, tetapi kenyataannya tidak demikian.

Kondisi pelayanan dan akses informasi hukum tersebut , apabila tidak segera ditanggulangi, dikhawarirkan dapat mematahkan semangat para pemakai jasa informasi hukum baik untuk penelitian, pendidikan, bisnis, penyelengaraan pemerintahan, dan penegakan hukum. Kondisi tersebut sekaligus juga mengindikasikan bahwa pelaksanaan Sistem Jaringan Dokumentasi \& Informasi Hukum di biro-biro hukum pemerintahan, lembaga peradilan, dan lembaga pemerintahan non departemen belum optimal. Akibat dari kondisi ini secara langsung menjadi kendala utama untuk penyebaran informasi hukum secara cepat, tepat, akurat, dan transparan.

Berdasarkan kondisi seperti itulah, peneliti terdorong untuk melakukan kajian mengenai efektivitas Sistem Jaringan Dokumentasi dan Informasi/SJDI Hukum di Daerah Istimewa Yogyakarta, dengan pertimbangan SJDI Hukum di DIY sudah dibentuk sejak tahun 1979. Namun demikian, apabila ditinjau dari pemakainya berdasarkan data 1999 s/d 2002 (akhir Februari) baru berjumlah 4.735 orang dengan koleksi yang dipinjam ada 6.823 judul. Jumlah pemakai ini bila dibandingkan dengan jumlah penduduk DIY yang berjumlah 3.327.954 jiwa (BPS DIY, 2001), ternyata masih sangat sedikit (0,14\%) yang memanfaatkan kegiatan SJDI Hukum.

Berdasarkan pemaparan dan latar belakang tersebut, maka dapat dirumuskan masalah yang menjadi kajian dalam tulisan ini yaitu faktor-faktor apa yang berpengaruh terhadap efektivitas SJDI Hukum di DIY ?. Dan bagaimana hubungan pengaruh antar faktor-faktor tersebut dengan efektivitas ?.

Parameter efektivitas yang digunakan dalam penelitian antara peneliti satu dengan lainnya ternyata berbeda-beda. Menurut Richard M. Steer (1985:5) menilai efektivitas organisasi sebagai ukuran seberapa jauh sebuah organisasi berhasil mencapai tujuan yang layak dicapai secara optimal. Seperti dikemukakan peneliti terdahulu (Katzel, 1975, cit. Steer, 1985), bahwa ukuran efektivitas berdasarkan prestasi dan produktivitas. Sedangkan Thorndike (1949) cit Steer (1985) kriteria efektivitas adalah produktivitas, laba bersih, penyelesaian misi, pertumbuhan, dan stabilitas organisasi. Campbell (1973) cit Steer (1985) mengukur efektivitas dengan 19 variabel, namun yang paling menonjol adalah keseluruhan prestasi, produktivitas, kepuasan kerja pegawai, laba, dan keluaran karyawan dengan variabel peramal misalnya gaya kepemimpinan. Gergopoulos dan Tannenbaum (1957) cit Steer (1985) meninjau efektivitas dari segi pencapaian tujuan suatu organisasi.

Richard M Steer (1985:8-11) menyebutkan variabel pokok yang berpengaruh terhadap efektivitas adalah: 1). karakteristik organisasi; 2). Karakteristik lingkungan; 3). Karakteristik pekerja; 4). Kebijakan dan praktek manajemen. Keempatnya berinteraksi satu sama lain dan secara serempak mempengaruhi keberhasilan atau kegagalan organisasi. Disamping itu keempat variabel ini memainkan peran penting dalam memperlancar terciptanya lingkungan kerja yang berorientasi pada prestasi.

Karakteristik organisasi terdiri dari struktur organisasi dan teknologi. Struktur sebagai susunan sumber daya manusia merupakan cara yang unik dari organisasi menyusun orang-orangnya untuk menyelesaikan pekerjaan. Sedangkan teknologi adalah mekanisme suatu organisasi untuk mengubah masukan mentah menjadi keluaran jadi, baik berupa variasi dalam proses, bahan, dan pengetahuan.

Karakteristik lingkungan meliputi lingkungan intern dan ekstern yang saling berhubungan. Lingkungan eksteren adalah semua kekuatan yang timbul di luar batas-batas organisasi dan dapat mempengaruhi keputusan serta tindakan di dalam organisasi yang dapat mempengaruhi derajad kestabilan, derajat kompleksitas, dan ketidakpastian. Sedang lingkungan intern yang lebih dikenal dengan iklim organisasi 
meliputi atribut lingkungan kerja (pekerja sentris, orientasi pada prestasi, sikap, dan prestasi)

Karakteristik pekerja, dimana pekerja yang berlainan mempunyai pandangan, tujuan, kebutuhan, dan kemampuan yang berbeda-beda. Variasi sifat manusia yang berbeda ini menyebabkan perilaku orang berbeda satu dengan yang lain, meskipun mereka ditempatkan di lingkungan kerja yang sama. Perbedaan-perbedaan individu ini juga dapat mempengaruhi langsung terhadap keterikatan dan prestasi kerja individu.

Kebijakan dan praktek manajemen, yaitu variasi gaya, kebijakan dan praktek kepemimpinan dapat memperlancar atau merintangi pencapaian tujuan organisasi yang akan dicapai. Kebijakan dan praktek manajemen ini meliputi penyusunan tujuan strategis,pencarian dan pemanfaatan sumber daya, menciptakan lingkungan prestasi, proses komunikasi, kepemimpinan dan pengambilan keputusan, inovasi, dan adaptasi organisasi.

Gibson (1966:33) mengatakan bahwa efektivitas dapat diukur dari kejelasan tujuan yang hendak dicapai, kejelasan strategi pencapaian tujuan, proses analisis dan perumusan kebijakan yang mantap, perencanaan yang matang, penyusunan program yang tepat, tersedianya sarana dan prasarana, sistem pengawasan, dan pengendalian yang bersifat mendidik.

Menurut Sulistyo-Basuki (1992) parameter efektivitas dalam sistem simpan dan temu balik informasi adalah rasio perolehan/recall dan rasio ketepatan /precision. Rasio perolehan adalah perbandingan dokumen ditemukan dengan jumlah total dokumen relevan dalam sistem. Sedang rasio ketepatan adalah perbandingan antara dokumen relevan dengan jumlah dokumen yang ditemukan dalam penelusuran.

Dalam penelitian ini efektivitas sebagai variabel terikat (Y) menggunakan parameter produktivitas, fleksibilitas, dan kepuasan kerja. Alasannya karena obyek penelitian (SJDI
Hukum) termasuk organisasi yang menyediakan jasa (informasi hukum), sehingga variabel kemampuan berlaba dan pencarian sumber daya tidak memberi pengaruh yang signifikan.

Sedang variabel bebas $(\mathrm{X})$ ditetapkan kemampuan SDM (X1), teknologi (X2), iklim organisasi (X3), komitmen anggota/kelompok (X4), dan gaya kepemimpinan (X5). Hubungan pengaruh antara variabel terikat dan bebas dinyatakan dalam hipotesis kerja yang dirumuskan sebagai berikut:"Terdapat hubungan signifikan antara kemampuan SDM, teknologi, iklim organisasi, komitmen anggota/kelompok dan gaya kepemimpinan terhadap efektivitas".

\section{METODE PENELITIAN}

Jenis penelitian ini termasuk deskriptif dengan menggunakan metode survei, yaitu menjelaskan hubungan antar variabel melalui pengujian hipotesis. Populasinya adalah unit SJDI Hukum di DIY yang berjumlah 24 unit. Berhubung pertimbangan biaya, tenaga, dan waktu yang dimiliki, maka subjek penelitian dibatasi dengan mengambil sampel yang berjumlah 5 unit SJDI Hukum. Penetapan sampel berdasarkan metode non random dalam kategori sampling bertujuan/ porpose sampling karena subjek penelitian bukan berdasarkan atas strata random atau daerah, tetapi didasarkan atas adanya tujuan tertentu yaitu pada instansi-instansi yang secara nyata telah aktif melaksanakan kegiatan SJDI Hukum. Respondennya pegawai di unit SJDI Hukum, namun yang dianalisis adalah organisaninya.

Metode pengumpulan data yaitu dengan menggunakan angket, wawancara, dan dokumentasi. Instrumen pengumpul datanya dengan skala Likert, pedoman wawancara, dan pedoman dokumentasi. Sumber data berasal dari sumber primer dan sekunder. Dalam penelitian ini juga dipakai metode pengukuran instrumen dengan uji validitas 
dan reliabilitas. Uji validitas dengan menggunakan korelasi Product Moment, sedang uji reliabilitas dengan rumus Cronbach Alpha $(\mu)$. Program yang dipakai untuk analisis data adalah SPSS for Windows versi 6.

\section{HASIL DAN PEMBAHASAN}

Penelitian ini dilaksanakan pada bulan Januari s/d Februari 2002 dengan memberikan angket sebanyak 42 bendel, dan yang kembali ada 42 bendel, berarti angket ini mendapat respon sebesar $100 \%$. Dari jumlah responden tersebut apabila ditinjau dari jenis kelaminnya, ada 23 orang (54,76\%) perempuan dan 19 orang (45,24\%) laki-laki. Lebih banyak perempuannya membuktikan bahwa unit ini lebih cocok untuk posisi perempuan, mengingat sifat pekerjaannya yang memerlukan ketelitian, ketekunan, dan kesabaran. Bila ditinjau dari latar belakang pendidikannya yang berijasah SLTP 4 orang $(9,52 \%)$, SLTA 21 orang $(50,80 \%)$, D 3 ada 3 orang $(7,14$ $\%)$, dan S1 berjumlah 14 orang (33,34 \%). Lulusan SLTA mendominasi karena secara teknis pekerjaan yang ada di unit SJDI Hukum mudah dipahami untuk orang yang mempunyai pendidikan setingkat SLTA, namun untuk pengembangannya tetap diperlukan orang yang berijasah S1 (khususnya Hukum). Masa kerja responden didominasi antara $0-5$ tahun sebanyak 18 orang $(42,86 \% 0)$, kemudian 5,1 -10 tahun ada 16 orang $(38,09 \%)$, sedang yang bermasa kerja 10,1 - 15 tahun berjumlah 6 orang $(14,29 \%)$. Hanya ada 2 orang $(4,76 \%)$ yang mempunyai masa kerja 15,1 - 20 tahun. Kondisi ini menyiratkan bahwa responden sering dimutasi karena tuntutan tugas maupun pengembangan kariernya. Responden yang telah mendapat bimbingan teknis tentang SJDI Hukum tingkat dasar ada 13 orang $(30,95 \%)$, tingkat lanjut ada 5 orang $(11,90 \%)$. Sisanya 24 orang $(57,15 \%)$ ternyata belum mendapat bimbingan teknis SJDI Hukum. Bila ditinjau usianya ternyata kelompok berusia muda 25 - 35 tahun ada 21 orang (50\%), kemudian kelompok tengah baya (36 - 45 tahun) ada 16 orang $(38,10 \%)$, sedang kelompok tua (46 - 55 tahun) berjumlah 5 orang $(11,90 \%)$. Sedang bila dilihat dari golongannya maka didominasi golongan II yang berjumlah 24 orang $(57,14 \%)$, golongan III ada 17 orang (40,48\%), dan golongan I hanya ada 1 orang $(2,38 \%)$.

Berdasarkan hasil penelitian ternyata tingkat efektivitas SJDI Hukum di DIY sebesar 4,22 yang diinterpretasikan efektif, walaupun belum sempurna (sangat efektif). Hal ini dikarenakan variabel-variabel bebas dalam penelitian (kemampuan SDM, teknologi, iklim organisasi, komitmen anggota/kelompok, dan gaya kepemimpinan) ternyata kondisinya belum optimal.

Dalam penelitian ini, tingkat signifikansi nilai diuji dengan menggunakan tesî yaitu membandingkan dengan harkat tabel pada tingkat signifikan tertentu yaitu $95 \%$. Artinya tingkat kebenarannya sebesar $95 \%$, dengan tingkat kesalahan 0,05. Syarat signifikan adalah F test $>$ F tabel dan dikatakan tidak signifikan bila $\mathrm{F}$ test $<\mathrm{F}$ tabel. Rumus yang dipakai adalah korelasi Product Moment dan Regresi Linier Berganda. Digunakan dua rumus korelasi dimaksudkan untuk mencari variabel yang benar-benar secara signifikan mempunyai pengaruh korelasi terhadap efektivitas.

Berdasarkan hasil perhitungan dengan rumus korelasi Product Moment Pearson, ternyata variabel kemampuan SDM mempunyai harga $\mathrm{F}$ test $<\mathrm{F}$ tabel $(1,063<1,684)$. Maknanya pengaruh korelasinya sangat rendah/tidak signifikan terhadap efektivitas. Berarti pendidikan formal dan non formal yang telah diikuti, pengalaman kerja dan masa kerja yang dijalani pengaruhnya sangat rendah terhadap efektivitas. Hal ini dikarenakan kegiatan unit SJDI Hukum secara teknis (pengadaan, pemrosesan, dan pelayanan) mudah dipahami oleh semua orang baik yang mempunyai pendidikan menengah, maupun tinggi. Terlebih pegawai yang sudah mengikuti bintuk, Diklat SJDI tingkat dasar dan lanjut, mengerjakan tugas teknis (yang memerlukan ketrampilan) terasa lebih mudah. Namun untuk pengembangan kegiatan 
yang memerlukan keahlian dan pendidikan tinggi tetap diperlukan.

Sedang variabel teknologi, iklim organisasi, dan komitmen anggota/kelompok mempunyai harga $\mathrm{F}$ test $>$ dari F tabel $(2,296>1,684 ; 4,668>1,684$; dan 3,704 > 1,684)> Kondisi ini mempunyai makna variabel-variabel tersebut mempunyai pengaruh yang signifikan terhadap efektivitas, walaupun dalam kisaran agak rendah sampai rendah. Hal ini disebabkan oleh belum optimalnya variabel teknologi dimanfaatkan mengingat masih ada kendala yang berkaitan dengan teknologi. Sedangkan untuk variabel iklim organisasi, ternyata di unit SJDI Hukum kurang berorientasi pada prestasi dan kepuasan kerja. Belum diterapkannya sistem imbalan dan hukuman dan masih ada rasa kurang aman dalam bekerja. Kemudian untuk variabel komitmen anggota/kelompok, ternyata hubungannya masih agak rendah. Kondisi ini bisa terjadi, karena pegawai yang sudah mengikuti diklat SJDI Hukum terpaksa dimutasikan di tempat lain demi tuntutan organisasi, sementara penggantinya ternyata orang-orang yang belum siap kerja di unit SJDI Hukum atau tidak jarang orang-orang yang ternyata "bermasalah" di tempat lain.

Khusus untuk variabel gaya kepemimpinan, pengaruhnya juga signifikan karena $\mathrm{F}$ test $>\mathrm{F}$ tabel $(5,541>$ 1,684), dalam intepretasi cukup. Berarti gaya kepemimpinan mempunyai pengaruh signifikan terhadap efektivitas. Pemilihan gaya kepemimpinan yang tepat bagi seorang pemimpin mempunyai pengaruh terhadap berhasil/tidaknya tujuan SJDI Hukum tercapai. Bila yang dipilih gaya demokratis/ partisipatif maka diharapkan efektivitas tercapai, sebaliknya bila gaya yang dipilih yang otoriter dan laissez-faire maka efektivitas sulit untuk diraih.

Pengaruh signifikan antara variabel dengan rumus Regresi Linier Berganda, bila dihitung secara bersama-sama semua variabel dengan efektivitas maka hasilnya variabel kemampuan SDM, teknologi, iklim organisasi, komitmen anggota/kelompok dan gaya kepemimpinan mempunyai korelasi yang signifikan terhadap efektivitas. Bila dibandingkan untuk variabel gaya kepemimpinan yang paling dominan berpengaruh terhadap efektivitas. Sedang bila variabel-variabel bebas $(\mathrm{X})$ dihitung secara sendiri-sendiri, maka variabel kemampuan SDM, teknologi, iklim organisasi dan komitmen anggota/kelompok tidak mempunyai pengaruh besar terhadap efektivitas. Khusus variabel gaya kepemimpinan mempunyai pengaruh besar terhadap efektivitas.

Jadi gaya kepemimpinan setelah dianalisis dengan rumus korelasi Product Moment Pearson dan Regresi Linier Berganda (baik secara bersama-sama maupun sendiri-sendiri) terbukti mempunyai pengaruh yang dominan terhadap efektivitas.

\section{KESIMPULAN DAN SARAN}

\section{Kesimpulan}

1. Berdasarkan analisis data dengan rumus korelasi Product Moment diperoleh hasil bahwa variabel kemampuan SDM pengaruhnya tidak signifikan terhadap efektivitas, sedang variabel teknologi, iklim organisasi, dan komitmen anggota/kelompok mempunyai pengaruh yang signifikan walau dalam kisaran yang rendah. Khusus variabel gaya kepemimpinan mempunyai pengaruh signifikan yang cukup terhadap efektivitas.

2. Berdasarkan analisis data dengan Regresi Linier Berganda diperoleh hasil bila dihitung secara bersama-sama antar variabel (kemampuan SDM, teknologi, iklim organisasi, komitmen anggota/ kelompok, dan gaya kepemimpinan, maka mempunyai pengaruh yang signifikan terhadap efektivitas. Namun apabila antar variabel tersebut dihitung secara sendir-sendiri, maka untuk variabel 
kemampuan SDM, teknologi, iklim organisasi, dan komitmen anggota/kelompok tidak mempunyai pengaruh besar terhadap efektivitas (karena T test lebih kecil dengan $T$ tabel yaitu $0,061<1,684 ; 1,013$ $<1,684 ; 1,038<1,684 ;$ dan $0,980<1,684)$. Sedang khusus untuk variabel gaya kepemimpinan mempunyai pengaruh besar terhadap efektivitas, karena $t$ test lebih besar dari t tabel $(2,248>1,684)$.

3. Dari analisis data baik berdasarkan rumus korelasi Product Moment maupun Regresi Linier Berganda ternyata variabel gaya kepemimpinan paling berpengaruh terhadap efektivitas. Kondisi ini mempunyai makna bahwa gaya kepemimpinan yang dimiliki oleh seorang pemimpin di unit SJDI Hukum mempunyai pengaruh sangat besar untuk dapat mengefektifkan atau justru menonaktifkan SJDI Hukum di DIY. Kenyataan ini sekaligus membuktikan bahwa sosok pemimpin masih menjadi panutan dan mempunyai pengaruh besar terhadap unit organisasi yang dipimpinnya.

Saran-saran

1. Walaupun hasil penelitian tidak ditemukan hubungan langsung antara kemampuan SDM dengan efektivitas, namun perlu ditingkatkan terus terutama untuk ilmu komputer agar dapat mengaplikasikan teknologi di unit SJDI Hukum di DIY.

2. Untuk variabel teknologi, iklim organisasi, komitmen anggota/kelompok perlu ditingkatkan perannya agar SJDI Hukum dapat mencapai efektivitasnya secara optimal. Dalam hal ini perlu ada campur tangan dari pemimpin mulai dari top manager sampai middle manajer untuk memberikan perhatian dan pemikirannya terhadap perkembangan kegiatan SJDI Hukum di DIY.
3. Gaya kepemimpinan yang dimiliki oleh seorang pemimpin di unit SJDI Hukum terbukti mempunyai pengaruh yang besar untuk dapat mengefektifkan organisasinya. Untuk itu bagi pemimpin yang teian memilih gaya kepemimpinan demokratis/partisipatif agar tetap dipertahankan. Dan bagi yang belum menentukan pilihan gayanya agar segera memilih gaya kepemimpinan demokratis/partisipatif ini.

\section{DAFTAR PUSTAKA}

Churchill, Gregory. 1989. Petunjuk Penelusuran Literatur Hukum Indonesia. Jakarta: PDH UI.

Gibson, James L. 1996. Organisasi: Perilaku, Struktur dan Proses, Ed. VIII jilid 1. Jakarta: Bina Aksara.

Indonesia.1996. Undang-undang Dasar 1945. Jakarta: BP-7 Pusat.

Reksodiputro, Mardjono. 2000. Proses Pemantapan dan Pengembangan Jaringan Dokumentasi dan Informasi Hukum (Sejak Tahun 1974 dan Arah Perkembangan Selanjutnya Yang Diharapkan). Makalah Pertemuan Berkala JDI Hukum ke-IX. Yogyakarta: 25 - 26 Juli.

Smits, Jan. 1991. Komputer: Suatu Tantangan Baru di Bidang Hukum (pengantar). Surabaya: Airlangga University Press.

Steers, Richard M. 1985. Efektivitas Organisasi; Kaidah Perilaku. Cet. 2. Jakarta: Erlangga.

Sulistyo-Basuki. 1992. Teknik dan Jasa Dokumentasi. Jakarta:Gramedia Pustaka Utama. 